\title{
EFFECT OF RUBBER PETIOLE CELL WALLS AND VIRULENCE OF STRAINS ON SECRETION OF PECTIC ENZYMES BY PYTOPHTHORA MEADII
}

\author{
K. E. Jayasuriya ${ }^{1}$, R. L. C. Wijesundera ${ }^{2}$ and B. I. Thennakoon ${ }^{1}$ \\ ${ }^{1}$ Department of Plant Pathology and Microbiology, Rubber Research Institute of Sri Lanka, Dartonfield, \\ Agalawatta, Sri Lanka, \\ ${ }^{2}$ Department of Botany, University of Colombo, Colombo 3, Sri Lanka. \\ Accepted 14 October 2007
}

\begin{abstract}
The characteristics of the pectic enzyme polygalacturonase (PG) of Phytophthora meadii isolates from petioles of rubber (Hevea brasiliensis) genotypes were compared in relation to (i) aggressiveness (virulence) in infecting detached petioles of a susceptible rubber genotype (PB86) or (ii) in relation to the availability of purified rubber petiole cell walls (obtained from a Phytophthora-resistant clone, RRIC100) in the growth medium, as the sole carbon source. The four most highly aggressive isolates produced PG forms varying within mw 48-60 kDa, while, the highly aggressive MAD86 isolate produced two PG forms of mw 48 and $70 \mathrm{kDa}$. Moderately or weakly aggressive isolates produced PG forms within the range of $62-66 \mathrm{kDa}$. With rubber petiole cell walls in the growth medium, the four most highly aggressive isolates produced PG forms of mw 42-62 kDa, while, MAD86 produced a much smaller PG form of $21 \mathrm{kDa}$. Weak or moderately aggressive isolates produced similar PG forms in both cell wall and pectin media. Quite smaller PG molecules produced in rubber cell wall medium could be due to elicitor molecular fragments bound to rubber cell walls, which may induce $P$. meadii to secret specific PG forms via signal transduction pathway. None of the isolates produced pectin lyase (PL) in any growth medium. Neither PG nor PL activity was detected in $P$. meadii-infected petioles.
\end{abstract}

Key Words: Cell wall degrading enzymes, resistance, Hevea brasiliensis, leaf disease

\section{INTRODUCTION}

Phytophthora species are ubiquitous in rubber [Hevea brasiliensis (A. Juss.) Muell. Arg.] plantations causing diseases such as leaf fall, bark rot, shoot die-back and pod rot, of which the first two cause direct yield losses. In Sri Lanka, these diseases are caused mainly by $P$. meadii McRae, compatibility type A1 (Danthanarayana et al., 1984). However, a previous study (Jayasuriya et al., 1999) has indicated that $P$. meadii isolates obtained from different rubber genotypes had markedly different degrees of virulence (Dv) in infecting petioles of a susceptible genotype PB86. The $P$. meadii isolates obtained from genotypes susceptible to Phytophthora leaf fall disease, such RRIC121 or PB86 were markedly more virulent than the isolates obtained from mildly to moderately susceptible (RRIC102) or highly resistant (RRIC100) genotypes. Therefore, the virulence of $P$. meadii may depend on the substrate from which it was originally isolated.
The role of cell wall degrading enzymes (CWDE) in penetration and colonisation of host tissues by plant pathogenic fungi has been well established (Walton, 1994; Wijesundera et al., 1989; Wood, 1967). Phytophthora capsici Leon. has been known to produce cellulase, xylanase, polygalacturonase, pectate lyase and $\beta$-glucosidase (Ferraris et al., 1996). Apart from CWDE, fungal cell wall-bound elicitors can activate host defence responses during early stages of pathogen attack (Ebel \& Scheel, 1997). These elicitors can be protein, glycoprotein or oligosaccharides and may have cultivar-specific activity (Blumwald et al., 1998; De Wit \& Spikman, 1982). Some structural carbohydrates such as oligogalacturonides, possibly released from plant cell walls during pathogenic invasion, may act as endogenous elicitors (Cotě \& Hahn, 1994). The cultivar specific elicitors may induce secretion of specific CWDE, which are more efficient in penetrating the host cell wall. The symptoms of the diseases caused by $P$. meadii on rubber plants suggest that CWDE may have an important role in accelerating the fungal colonisation of tissues. However, there have

*Corresponding author's email: kithsiri.jayasuriya@yahoo.com 
been no studies on CWDE production by $P$. meadii isolates or elicitor responses by rubber plants against $P$. meadii infections. Therefore, the objective of the present investigation was to characterise and compare the activities of pectic enzymes of $P$. meadii isolates in relation to defence responses from different rubber genotypes to $P$. meadii elicitors.

\section{MATERIALS AND METHODS}

\section{Phytophthora meadii isolates}

Phytophthora meadii was isolated from infected petioles or bark tissues of rubber genotypes cultivated in Sri Lanka. Isolates DER100 and PEE100 were obtained from petioles of the genotype RRIC100 which is resistant to Phytophthora leaf and bark rot disease (Jayasinghe, 1992, 1995), while PEE102b was obtained from bark tissues of the genotype RRIC102, which is mild to moderately susceptible to leaf disease (unpublished data). ARA121 isolate was obtained from petioles of the genotype RRIC121 which is susceptible to leaf disease and resistant to bark rot disease (Jayasinghe, 1995). Isolate GL130 was obtained from petioles of the genotype RRIC130, which is moderately resistant to leaf disease and susceptible to bark rot disease (Jayasinghe, 1995). DF600 (IMI385260) isolate was obtained from petioles of the genotype RRIM600, which is susceptible to leaf disease (Jacob et al., 1989). Isolate ELS105b was obtained from bark tissues of the genotype RRII105 of India, which is resistant to leaf fall disease (Jacob et al., 1989). MAD86 (IMI385259) was obtained from the genotype PB86, which is susceptible to both diseases (Jayasinghe, 1996). The isolation, purification and maintenance of cultures were done as described previously (Jayasuriya et al., 1999).

\section{Isolation of rubber plant cell walls from petioles}

Fifty well-matured petioles, obtained from 10 trees of clone RRIC100 were homogenised with $0.1 \mathrm{M}$ phosphate buffer $(\mathrm{pH} 7.0)$ in a commercial blender for $10-15 \mathrm{~min}$. The suspension was filtered through Whatman No 1 filter paper and the residue on filter paper was washed five times with $\mathrm{CHCl}_{3}$ : methanol $(\mathrm{MeOH})(1: 1, \mathrm{v} / \mathrm{v})$ in a suction funnel and the solvent was removed by applying vacuum for 15 min. Cell wall particles were finally washed twice with acetone to remove any pigments (Ferraris et al., 1996). The residue was air-dried and ground to a fine powder using a mill and stored at $-20^{\circ} \mathrm{C}$ until used.

\section{Enzyme sample preparation from liquid media having pectin or petiole cell walls as the sole carbon source}

Cultures of $P$. meadii were grown in ammoniumtartrate liquid medium (Byrde \& Fielding, 1968) containing either citrus pectin (Sigma) $\left(10 \mathrm{~g} \mathrm{l}^{-1}\right)$ or isolated rubber plant cell walls $\left(0.5 \mathrm{~g} \mathrm{l}^{-1}\right)$ as the main carbon source. Batches of $50 \mathrm{ml}$ liquid medium in $250 \mathrm{ml}$ conical flasks were autoclaved for $20 \mathrm{~min}$ at $121^{\circ} \mathrm{C}$. Flasks were cooled to $27 \pm 2^{\circ} \mathrm{C}$ and were inoculated with a $5 \mathrm{~mm}$ disc of mycelium obtained from the growing edge of $P$. meadii cultures. These were subsequently incubated at $27 \pm 2{ }^{\circ} \mathrm{C}$ under natural light and dark conditions for 28 days. The culture filtrates were obtained on every other day commencing from the $2^{\text {nd }}$ day after inoculation, by filtering through Whatman No 1 filter paper and were used immediately to assay enzyme activity or freeze dried for molecular weight determinations. This procedure was repeated three times.

\section{Enzyme sample preparation from $P$. meadii- infected petiole tissues}

Ten petioles obtained from rubber plants of clone PB 86 were placed on glass rods fixed on to the base of a plastic tray and inoculated with standardised zoospore suspensions of $P$. meadii isolate MAD86 as described previously (Jayasuriya et al., 1999). After incubation for three days at $27 \pm 2^{\circ} \mathrm{C}$ under natural light and dark conditions, tissues were excised from the necrotic sites along with healthy margins (Fielding, 1981) and $3 \mathrm{~g}$ were ground in a chilled mortar in $30 \mathrm{ml}$ of $100 \mathrm{mM}$ Tris- $\mathrm{HCl}$ buffer $(\mathrm{pH}$ 7.6) containing cystein hydrochloride $\left(10 \mathrm{mg} \mathrm{l}^{-1}\right)$ and $1 \mathrm{M} \mathrm{NaCl}$. The suspension was kept for $1 \mathrm{~h}$ at $4^{\circ} \mathrm{C}$ and the extract was filtered through a few layers of muslin and centrifuged $5 \mathrm{~min}$ at 2000 g. Enzyme activities of the supernatant were assayed as described below. An extract obtained similarly from $3 \mathrm{~g}$ of healthy tissue served as the control. This was repeated three times.

\section{Pectin-lyase assays}

Pectin-lyase (PL) was measured in the culture filtrates according to the thiobarbituric acid method (Fielding, 1981). The absorbance was read using Camspec M330 (UV/visible) spectrophotometer at $550 \mathrm{~nm}$ and PL activity and was expressed as arbitrary units over a particular period at $27 \pm 2^{\circ} \mathrm{C}$. Average values were obtained from two separate experiments, which had three replicates at each given time. 


\section{Polygalacturonase assay}

Polygalacturonase (PG) activity in P. meadii isolates grown in liquid culture filtrates and obtained after different time intervals was determined according to Fielding and Byrde (1969) with modifications. The PG activity was measured arbitrarily in terms of reduction of viscosity of a $1.5 \%$ sodium polypectate solution caused by disruption of polypectate. The PG enzyme solution $(4 \mathrm{ml})$ obtained as described above was added to $10 \mathrm{ml}$ of $1.5 \%(\mathrm{w} / \mathrm{v})$ aqueous solution of sodium-polypectate $(\mathrm{pH}$ 5.0) in $200 \mathrm{mM}$ sodium acetate buffer and the whole solution $(14 \mathrm{ml})$ was passed through an Oswald viscometer at $27 \pm 2^{\circ} \mathrm{C}$. The enzyme activity was expressed as arbitrary units (AU) of the \% viscosity reduction per $\mathrm{h}$ [PG Enzyme activity $=$ $\left(1 / t_{i}-t_{2}\right) / t_{i} \times 100$, where $t_{I}=$ time (s) to pass $14 \mathrm{ml}$ of enzyme solution, representing the initial viscosity of the sodium polypectate solution, and $t_{2}=$ time (s) to pass the same volume of enzyme solution after $1 \mathrm{~h}$ incubation period representing the viscosity after incubation. The experiment was repeated three times using three replicates per isolate each time.

\section{Determination of molecular weights of polygalacturonase}

The molecular weight of PG was determined from 10 day-old culture filtrates $(50 \mathrm{ml})$ obtained from $P$. meadii isolates grown in ammonium tartrate liquid medium (Byrde \& Fielding, 1968) containing either citrus pectin (Sigma) or isolated cell walls (Wijesundera et al., 1984) as its main carbon source. The filtrates were dialysed (Visking size 3 diameter 20/32" $15.9 \mathrm{~mm}$ ) against distilled water for $48 \mathrm{~h}$ at $4^{\circ} \mathrm{C}$ and freeze-dried. The freeze-dried concentrates were dissolved in a minimum volume $(1.5-2 \mathrm{ml})$ of $0.05 \mathrm{M}$ Tris-HCl buffer ( $\mathrm{pH}$ 7.6) and applied to a column $(1.6 \times 70 \mathrm{~cm})$ of Sephadex G-75 (Pharmacia). The column was eluted with 50 $\mathrm{mM}$ Tris- $\mathrm{HCl}$ buffer ( $\mathrm{pH}$ 7.6), which contained $10 \mathrm{mM} \mathrm{KCl}$ and $0.2 \%$ sodium azide, at a flow rate of $0.5 \mathrm{ml} \mathrm{min}^{-1}$ (Andrews, 1964). Eluted fractions $(3 \mathrm{ml})$ were collected and the absorbance was measured at $280 \mathrm{~nm}$ using a Camspec M330 (UV/visible) spectrophotometer. Peak fractions were pooled, freeze-dried and PG activity was verified individually for each pooled fraction by cup plate assay as described by Dingle et al. (1953) and by the viscosity method (Fielding et al., 1969). The column was pre-calibrated with marker proteins such as cytochrome $\mathrm{C}$ horse heart, Bovine serum albumen, and carbonic-anhydrase (Sigma) by applying $2 \mathrm{mg}$ of each marker protein dissolved in $2 \mathrm{ml}$ eluting buffer (Andrews, 1964). The test was repeated three times.

\section{RESULTS}

Production of pectic enzymes in liquid medium containing pectin

According to the viscosity test results (Figs. $1 \& 2$ ), culture filtrates of $P$. meadii isolates having varied aggressiveness produced different peaks of PG activity. A majority of the isolates produced PG in the early stages of incubation having 2-3 activity peaks. The weak isolates (DF600 and ELS105b) had low levels of PG activity during the first 4-6 days reaching peaks on $8^{\text {th }}$ or $10^{\text {th }}$ day respectively. In filtrates of highly aggressive isolates (MAD86, PEE102b, ARA121 and GL130), PG activity peaked earlier than that for the weak (DF600 and ELS105b) isolates.

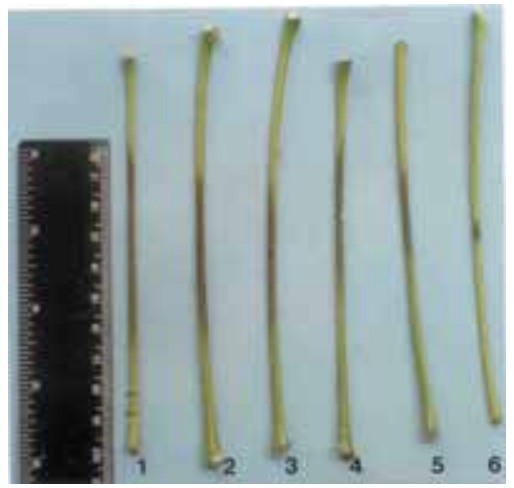

Figure 1. Aggressiveness of Phytophthora meadii McRae isolates obtained from Hevea brasiliensis genotypes. The averages of the lengths (mm) of lesions caused by, 1 . MAD86 (IMI385259), 2. PEE102b, 3. ARA121, 4. GL130, 5. PEE100, 6. DF600 (IMI 385260) on petioles of clone PB86 was considered as the arbitrary unit of the aggressiveness of each isolate. 

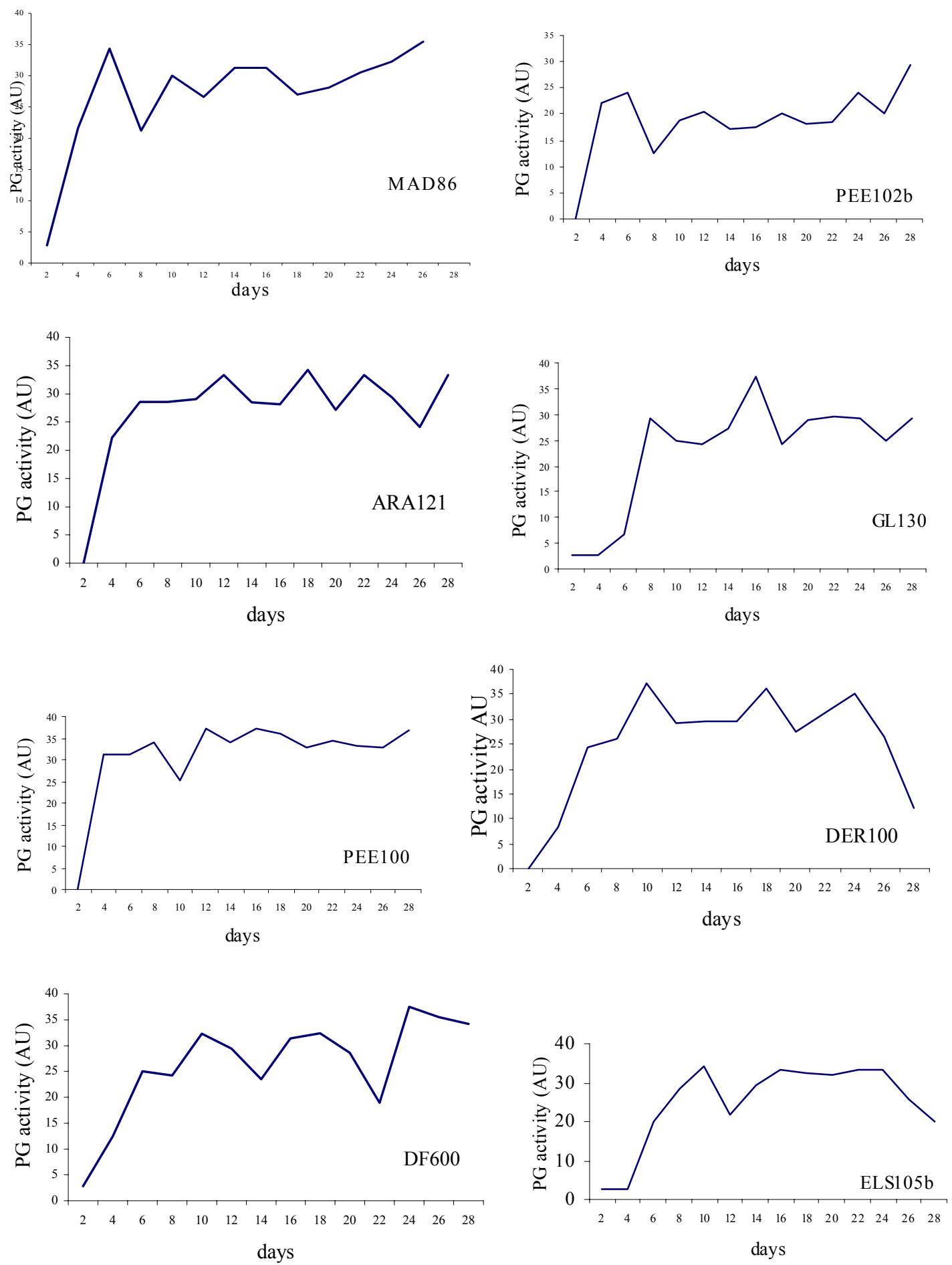

Figure 2. Polygalacturonase enzyme activity Phytophthora meadii isolates in liquid medium containing pectin as the sole carbon source. $\mathrm{AU}=$ arbitrary units.Production of pectic enzymes in liquid medium containing rubber plant cell walls. 
The peak pattern of PG activity of $P$. meadii in cell wall medium was similar to that observed in the medium that had pectin as the main carbon source (Fig. 2). The highly aggressive MAD86 produced two peaks of PG activity in both media, indicating its proper adaptability for successful invasion of host tissues using different PG forms.

\section{Production of pectic enzymes in tissues}

Although all $P$. meadii isolates produced $P G$ in both liquid media, neither PG nor PL was detectable in petiole extracts obtained from the necrotic sites that resulted from inoculation with isolate MAD 86.

\section{Characterisation of polygalacturonase of $\boldsymbol{P}$. meadii}

The PG produced in pectin medium had mw 48-70 kDa (Table 1). Although several peaks were present, all isolates appeared to produce only one form of PG except MAD86, which had two forms. Results suggest that moderately or weakly aggressive isolates such as DER100, PEE100, PEE86, DF600 and ELS105b produced similar forms of $\mathrm{PG}$ in the range of $62-66 \mathrm{kDa}$, while highly aggressive isolates such as GL130, ARA121, PEE102b, and MAD86 produced forms in the range of $\mathrm{mw} 48-60 \mathrm{kDa}$. Weak isolates produced same PG forms in the medium with rubber cell walls, whereas the aggressive isolates produced PG forms of smaller mw at 21$62 \mathrm{kDa}$. It was notable that, in each medium the most aggressive, MAD86 produced PG of the lowest mw.

\section{DISCUSSION}

Early secretion of PG by virulent $P$. meadii may not only increase the chance to achieve a more intimate contact between the enzyme and its substrate but also the successful establishment in host tissues. None of the isolates produced PL enzymes in any liquid medium used in this experiment, and the lack of PL also confirmed the earlier findings of Ann and Ko (1989), that described the entire genus of Phytophthora as poor producers of pectolytic enzymes.

Absence of PG or PL in infected petioles was similar to the observations made with other fungi such as Colletotrichum lindemuthianum (Wijesundera et al., 1989). Several reasons such as secretion in very low concentrations, ionic binding to negatively charged cell walls and vascular elements (Cooper, 1983; Cooper \& Wood, 1980; Keon et al., 1987), and inhibition by plant proteins during extraction (Ferraris et al., 1996) have been proposed as possible explanations of this phenomenon. Thus, the nondetection of PG in infected tissues does not rule out its involvement in the development of infection. The characteristics of $\mathrm{PG}$ of P. meadii isolates reported in this study are in agreement with some other fungi (Ferraris et al., 1996; Ayers et al., 1966; Collmer \& Keen, 1986).

Table 1. Aggressiveness and characterisation of polygalacturonase enzymes of $P$. meadii isolates.

\begin{tabular}{|c|c|c|c|}
\hline \multirow{2}{*}{ P. meadii isolates } & \multirow{2}{*}{ Aggressiveness $^{\S}$} & \multicolumn{2}{|c|}{ MW $(\mathrm{kDa}) *$ of $P G$ in media with } \\
\hline & & Citrus pectin & Cell walls \\
\hline \multirow[t]{2}{*}{ MAD86 (IMI 385259) } & $55.6 \pm 3.3$ & $48 \pm 0.05$ (form 1) & $21 \pm 0.8$ \\
\hline & & $70 \pm 0.2($ form 2$)$ & $62 \pm 0.2$ \\
\hline PEE102b & $50.6 \pm 1.5$ & $48 \pm 0.8$ & $45 \pm 0.2$ \\
\hline ARA121 & $48.3 \pm 3.1$ & $48 \pm 1.7$ & $44 \pm 0.8$ \\
\hline GL130 & $45.6 \pm 3.2$ & $60 \pm 0.8$ & $42 \pm 0.6$ \\
\hline DER100 & $27.6 \pm 8.5$ & $62 \pm 0.5$ & $62 \pm 0.3$ \\
\hline PEE100 & $10 \pm 2.6$ & $66 \pm 0.8$ & $66 \pm 0$ \\
\hline PEE86 & $10.2 \pm 1.5$ & $66 \pm 0.5$ & $66 \pm 0.5$ \\
\hline DF600 (IMI 385260) & $9.90 \pm 1.3$ & $66 \pm 0.6$ & $66 \pm 0.5$ \\
\hline ELS105b & 0 (no infection) & $66 \pm 0$ & $66 \pm 0.5$ \\
\hline
\end{tabular}

\footnotetext{
*Results are averages of 3 replicates \pm SEM, ${ }^{\S}$ Source: Jayasuriya et al. (1999)
} 
The aggressive $P$. meadii isolate has produced a PG form with lower $\mathrm{mw}$ in the medium containing rubber cell walls, possibly, as a result of an activation of a signalling molecule via the signal transduction mechanism. Similarly, when Trichoderma harzianum or $T$. viride were grown on cell walls of Rhizoctonia solani, several extra-cellular proteins have been reported to be induced in Trichoderma (Robertsen, 1986), indicating an induction by elicitors bound to the cell walls of $R$. solani. Rubber cell walls applied to the medium were of the genotype RRIC100, which is resistant to Phytophthora spp., and thus may contain genotype-specific proteins, which may have the ability to perceive signals of $P$. meadii. Since protein fraction of rubber cell walls has not been characterized, it is difficult to determine the nature of the signalling molecules that are responsible for triggering the pathogen cell wallbound elicitors and the mechanism of its activation. Therefore, it would be useful to characterise and identify the structures of such proteins, and also to determine the effect of rubber cell walls obtained from petioles of a Phytophthora-susceptible genotype such as PB86

The activity of cell wall degrading enzymes in plant tissue have been reported to be dependent on size, the smaller molecules having more mobility or access to substrates (Ayers et al., 1966). Therefore, the presence of low mw forms of PG may contribute to high virulence of P. meadii (Collmer \& Keen, 1986).

\section{ACKNOWLEDGEMENTS}

The authors acknowledge the Sri Lanka Council of Agricultural Research Policy (CARP) for the grant CARP/12/373/299 awarded to the senior author. Mr. Tharanga Widyawardena, Ms. Nilakshi Silva, Esmi Karunarathna and the staff of the Department of Plant Pathology \& Microbiology of the Rubber Research Institute are acknowledged for technical assistance.

\section{REFERENCES}

Andrews, P. (1964). Estimation of molecular weights of proteins by sephadex gel-filtration. Journal of Biochemistry 91:222-233.

Ann, P. J., Ko, W. H. (1989). Survey of enzyme activity on solid media in Phytophthora. Canadian Journal of Botany 68: 139-143.
Ayers, W. A., Papavizas, G. C., Diem, A. F. (1966). Polygalacturonate transeliminase and polygalacturonase production by Rhyzoctonia solani. Phytopathology 56: 1006-1011.

Blumwald, E., Aharon, G. S., Lam, B. C. H. (1998). Early signal transduction pathways in plant-pathogen interactions. Trends in Plant Science 3: 342-346.

Byrde, R. J. W., Fielding, A. H. (1968). Pectin methyl-transeliminase as the macerating factor of Sclerotinia fructigena and its significance in brown rot of apple. Journal of General Microbiology 52: 287-297.

Collmer, A., Keen, N. T. (1986). The role of pectolytic enzymes in plant pathogenesis. Annual Review of Phytopathology 24: 383-409.

Cooper, R. M., Wood, R. K. S. (1980). Cell wall degrading enzymes of vascular wilt fungi III. Possible involvement of endo-pectin lyase in Verticillium wilt of tomato. Physiological Plant Pathology 16: 285-300.

Cooper, R. M. (1983). The mechanism and significance of enzymic degradation of host cell walls by arasites In: Callow, J. A. (Ed), Biochemical Plant Pathology, John Wiley and Sons, London, 101-135.

Coté, F., Hahn, M. G. (1994). Oligosaccarins: structures and signal transduction, Plant Molecular Biology 26: 1379-1411.

Danthanarayana, D. M., Peries, O. S., Liyanage, A. De S. (1984). Taxonomy of Phytophthora species solated from rubber in Sri Lanka. Transactions of the British Mycological Society 82:113-126.

De Wit, P. J. G. M., Spikman, G. (1982). Evidence for the occurrence of race and cultivarspecific elicitors of necrosis in intercellular fluids of compatible interactions of Cladosporium fulvum and tomato. Physiological Plant Pathology 21: 1-11.

Dingle, J., Reid, W. W., Solomons, G. L. (1953). The enzyme degradation of pectin and other polysaccharides. II. Application of the "cupplate" assay to the estimation of enzymes. Journal of Science Food and Agriculture 4: 149155. 
Ebel, J., Casio, E. G. (1994). Elicitors of plants defense responses. International Review of Cytology 148: 1-36.

Ebel, J., Scheel, D. (1997). Signals in hostparasite interactions In: Carroll G C, Tudzynski P, (Eds), The Mycota V Part A. Plant Relationships, Springer-Verlag Berlin Heidelberg, 85-105.

Ferraris, L., Cardinale, F., Matta, A. (1996). In vitro production of cell wall degrading enzymes by Phytophthora capsici Leon. Phytopathologia Meditereniana 35:199-206.

Fielding, A. H., Byrde, R. J. W. (1969). The partial purification and properties of endopolygalacturonase and $\propto$-L-arabinofuranosidase secreted by Sclerotinia fructigena. Journal of General Microbiology 58: 73-84.

Fielding, A. H. (1981). Natural inhibitors of fungal polygalacturonases in infected fruit tissues. Journal of General Microbiology 123: 377-381.

Jacob, C. K., Edathil, T. T., Idicula, S. P., Jayarathnam, K., Sethuraj, M. R. (1989). Effect of abnormal leaf fall occurred by Phytophthora spp. on the yield of rubber tree. Indian Journal of Natural Rubber Research 2: 77-80.

Jayasinghe, C. K. (1992). Review of the Department of Plant Pathology and Microbiology. Annual Review of the Rubber Research Institute of Sri Lanka. 46-57.

Jayasinghe, C. K. (1995). Review of the Department of Plant Pathology and Microbiology. Annual Review of the Rubber Research Institute of Sri Lanka. 53-72.

Jayasinghe, C. K. (1996). Review of the Department of Plant Pathology and Microbiology Annual Review of the Rubber Research Institute of Sri Lanka. 45-57.
Jayasuriya, K. E., Wijesundera, R. L. C., Jayasinghe, C. K., Thennakoon, B. I. (1999). A comparative study of Phytophthora meadii isolates from rubber (Hevea brasiliensis) plantations in Sri Lanka. Mycopathologia 147:125-132.

Keon, J. P. R., Byrde, R. J. W., Cooper, R. M. (1987). Some aspects of fungal enzymes that degrade plant cell walls, In: Pegg, G. F., Ayres, P. G. (Eds), Fungal infection of plants, Cambridge University Press, Cambridge. 133 p.

Robertsen, B. (1986). Elicitors of the production of lignin-like compounds in cucumber hypocotyls. Physiological and Molecular Plant Pathology 28: 137-148.

Walton, J. D. (1994). Deconstructing the cell wall. Plant Pathology 104: 1113-1118.

Wijesundera, R. L. C., Bailey, J. A., Byrde, J. W. (1984). Production of Pectin lyase by Colletotrichum lindemuthianum in culture and in infected bean (Phaseolus vulgaris) tissue. Journal of General Microbiology 130: 285-290.

Wijesundera, R. L. C., Bailey, J. A., Byrde, R. J. W., Fielding, A. H. (1989). Cell wall degrading enzymes of Colletotrichum lindemuthianum: their role in the development of bean anthracnose. Physiological and Molecular Plant Pathology 34: 403-413.

Wood, R. K. S. (1967). Cell wall degrading enzymes in different plant diseases, In: James, W. O., Burnett, J. H. (Eds). Physiological Plant Pathology, Blackwell Scientific Publications, Oxford. 154-187. 